\title{
Analyzing the Relationship between Student's Assignment Submission Behaviors and Course Achievement through Process Mining Analysis
}

\author{
Gökhan Akçapınar and Mehmet Kokoç ${ }^{\mathrm{b}}$ \\ ${ }^{\mathrm{a}}$ Hacettepe University, Faculty of Education, Ankara/Turkey, (ORCID: 0000-0002-0742-1612) \\ ${ }^{\mathrm{b}}$ Trabzon University, Fatih Faculty of Education, Trabzon/Turkey, (ORCID: 0000-0002-1347-8033)
}

Article History: Received: 30 March 2020; Accepted: 20 June 2020; Published online: 29 June 2020

\begin{abstract}
In this study, it is aimed to analyze the relationship between student's assignment submission behaviors and course achievement. For this purpose, the behaviors of 75 students' who enrolled in the Operating Systems and Applications course at a public university, submission an assignment through the Moodle learning management system given in the fourth week of the course is analyzed. Students who exhibit different assignment submission behaviors are also analyzed in terms of endof-term grades. During analyzing, the steps followed by the students while submitting their assignments are determined respectively, and students who display a similar pattern are divided into groups by means of cluster analysis. Moreover, using process mining analysis assignment submission processes of students in different groups are analyzed in detail. The analysis shows that students can be divided into three different groups based on their assignment submission behaviors. In terms of course achievement, it is observed that a significant portion of the students who submitted the assignments are successful in the course, while a significant portion of the students who did not submit the assignment failed. The findings will be guideway in determining the students who are likely to fail the course in the early weeks and in designing possible interferences for these students.
\end{abstract}

Keywords: Learning analytics, assignment, educational data mining, clustering, process mining, Moodle

DOI: $10.16949 /$ turkbilmat.711683

Öz: Bu çalışmada üniversite öğrencilerinin ödev gönderme davranışları ile ders başarıları arasındaki ilişkinin incelenmesi amaçlanmıştır. Bu amaçla, bir devlet üniversitesinde İşletim Sistemleri ve Uygulamaları dersine kayıtlı 75 öğrencinin Moodle öğrenme yönetim sistemi üzerinden dersin dördüncü haftasında verilen bir ödevi gönderme davranışları analiz edilmiştir. Aynı zamanda farklı ödev gönderme davranışı sergileyen öğrenciler dönem sonu notları açısından da analiz edilmiştir. Analiz aşamasında, öğrencilerin ödev gönderirken izledikleri adımlar sıralı olarak belirlenmiş ve kümeleme analizi yardımı ile benzer örüntü sergileyen öğrenciler gruplara ayrılmıştır. Aynı zamanda süreç madenciliği analizi kullanılarak farklı gruplardaki öğrencilerin ödev gönderme süreçleri detaylı olarak analiz edilmiştir. Yapılan analizler, öğrencilerin ödev gönderme davranışlarına göre üç farklı gruba ayrılabileceğini göstermiştir. Ders başarısı açısından bakıldığında ise ödevi gönderen öğrencilerin önemli bir bölümünün dersten başarılı olduğu gözlemlenirken, ödev gönderiminde bulunmayan öğrencilerin önemli bir bölümünün dersten başarısız olduğu görülmüştür. Elde edilen bulgular, dersten başarısız olma ihtimali yüksek olan öğrencilerin erken haftalarda belirlenmesinde ve bu öğrencilere yönelik olası müdahalelerin tasarlanmasında yol gösterici olacaktır.

Anahtar Kelimeler: Öğrenme analitikleri, ödev, eğitsel veri madenciliği, kümeleme, süreç madenciliği, Moodle

Türkçe sürüm için tıklayınız

\section{Introduction}

Traces of log records that derived from learner interactions in online learning environments guide researchers to understand students' learning processes. The data obtained in this way are analyzed by machine learning methods, and used for different purposes such as predicting students' academic achievement, determining the strategies they follow while preparing for the course. The interest of researchers in these studies, which falls under the titles of learning analytics, educational data mining, and artificial intelligence in education, has been increasing in recent years. In relevant studies, significant tangible outcomes have been produced for both online learning and other learning models supported by online learning. Following a similar approach, this study aims to model the assignment submission behaviors of students by putting to use the clustering and process mining analysis, and to examine the relationship between the revealed profiles and the course achievement of the students.

\subsection{Online Learning Experiences in terms of Blended Learning}

Blended learning environments which are supported by online learning activities promote students' learning processes significantly. Supporting face-to-face lessons at higher education level through online learning environments provides more flexible learning opportunities for students and instructors compared to face-to-face learning environments (Graham, 2006; Symth, Houhton, Cooney, \& Casey, 2012). The things that count at this 
point is to designate how effective learning experiences emerge in the blended learning process by considering individual differences and to use the obtained results in the terms of learning design.

It is reflected in the outcomes of studies that the individual characteristics and online learning experiences of students have a significantly impact on course achievement and learning outcomes. Some studies in the related literature; shows that students' individual characteristics such as self-efficacy, self-regulation skills, academic procrastination, technology literacy, locus of control have a significant role on the effectiveness of blended learning (Broadbent, 2017; Prasad, Maag, Redestowics, \& Hoe, 2018; Rasheed, Kamsin, \& Abdullah, 2020). In this regard, it is emphasized that the fulfilling of the learning design based upon the individual characteristics of the students increases the interaction and flexibility in blended learning and makes the learning process more efficient (Porter, Graham, Spring, \& Welch, 2014). After all, to make blended learning effective, students' online learning experiences need to be deeply understood based on behavioral data (Kokoç \& Altun, 2019).

Analysis of learning analytics data is substantial in terms of understanding the online learning experiences of the students in the online learning process and predicting the students' online learning performance. In this regard, there have been studies in the literature that aim predicting learning outcomes based on log data collected from online learning environments. Zacharis (2015), as part of a programming language course conducted through blended learning, it is examined whether students' interaction logs predicted their end-of-term achievements or not. It is determined that 14 out of the 29 variables produced based on interactions on the Moodle learning management system are significant in predicting students' final grades; and four interaction variables (reading and sending messages, contributing to content creation, efforts on exam and number of files displayed) explained $52 \%$ of the variance in the final grades. In a study conducted by Jo, Park, Kim, and Song (2014), it is investigated whether students' online behavior influence predicting learning performance in blended learning environments. Within the scope of the study, data collected from two different blended learning lessons supported by learning management system are processed. The regression model that emerged as a result of the analysis shows that the interaction data reflecting the students' online learning behavior can markedly predict $70 \%$ of the variance in learning performance. Moreover, in another study, an early warning system is developed to estimate the academic performance of the at-risk students by using learning analytics data in a Computer Hardware course conducted through blended learning (Akçapınar, Altun, \& Aşkar, 2019). As a result of the study in which different classification algorithms are put to work; It is revealed that the prediction models created based on the interaction data of the students can predict the students who are going to fail in the third week of the course. In the study carried out by Lu et al. (2018), unlike other studies, it is determined that student data in both face to face and online learning environment played a statistically significant role in predicting student performance in the context of blended learning. The results of the background studies prove that interaction data obtained from students' online learning experiences are effective in predicting student performance in the context of blended learning.

In the scope of blended learning, students' online learning experiences are correlate with the learning resources, activities, and tasks offered to them during the learning process. Kokoç and Altun (2019) found that students' online interaction data are grouped under six factors and these factors reflect online learning experiences of students. Online assignments are one of the learning activities that play a crucial role in the occurrence of effective online learning experiences. Therefore, in the scope of learning analytics, it will be useful to address students' interactions with online assignments and learning tasks, to be well understood their learning experiences.

\subsection{Online Assignments and Learning Analytics Studies}

Assignment is a frequently used learning activity to test the effectiveness of the learning process. Online learning by definition, students are expected to be more responsible for their own learning processes (Dabbagh \& Kitsantas, 2005). Therefore, students who fulfill the responsibility of online learning tasks and complete their learning tasks on regular basis are defined as successful ones (You, 2016). It is known that students who complete and submit at least one online assignment are more likely to accomplish distance learning courses (Lim, 2016). At this point, excepting the number of assignment completions, the question how students interact with online assigment and learning tasks pages arises.

The data of assignment interactions generally correspond to the number of times students upload their assignment files on learning tasks, the time they spend on assignment pages, and the frequency and duration of exams provided by instructors. It is seen in the literature on learning analytics that there are leastwise studies on the relationship of students' assignment interactions and learning performances. MacFadyen and Dawson (2010) investigated the relationship between students' academic performance and interaction data through logistic regression analysis. It is concluded that the number of completed online assignments is one of the important variables that predict students' end-of-term achievements. In a study carried out in the scope of a blended learning process supported by Moodle learning management system, it was found that the number of students' assignment submission predicted students' final grades significantly (Zacharis, 2015). However, in some studies 
that aim to predict student's success in blended learning environments, it is determined that the marks students get from weekly online assignments are a significant predictor of learning performance (Huang \& Fang, 2013; Lu et al., 2018). Another study purposes to estimate the academic performance of students based on their efforts in performing their learning tasks (Kovanovic et al., 2015). Findings obtained from different regression models are shown that students' frequency of viewing assignments pages and the time they spend on assignments are important in predicting their academic performance. Therefore, the results of the relevant research indicate that the interactions of students regarding learning tasks and assignments play a significant role in gaining efficient online learning experiences in blended learning environments.

Some of the studies that show the importance of students' assignment submitting, regarding blended learning behaviors, are related to academic procrastination. Academic procrastination is associated with variables such as whether students submit their assignments and whether they submit them late or not, and the simultaneously effort on assignment as an individual or group. Although a study conducted in the context of blended learning found that there is no significant relationship between students' tendency to postpone their academic tasks and time to submit activities (Bayrak, 2018), it is emphasized that assignment submitting behaviors are substantial indicators of academic procrastination and affect course success. One of the studies on this topic is aimed at modeling together with learning performances by examining students' interaction and procrastination behaviors as a part of blended learning (Cerezo, Esteban, Sánchez-Santillán, \& Núñez, 2017). In the relevant study, the number of days that students wait to check their weekly assignments is considered as the interaction variable associated with procrastination. In the study in which the Association Rule Mining analysis is put to work, the obtained rules set forth with high confidence indicate that the students who submit late assignments will underperform. In the study carried out by You $(2015,2016)$, it is concluded that the assignments are submitted late or not has a significant negative effect on the students' grades and exam scores. In the related study, assignment submitting behaviors are considered as an indicator of academic procrastination. In other studies of similar nature, it is concluded that the learning performance will be higher as the time taken until the students upload their assignments shorten (Paule-Ruiz, Riestra-Gonzalez, Sánchez-Santillan, \& Pérez-Pérez, 2015). On the other hand, when the students perform their learning tasks late and the time it takes to submit the assignment longer, their learning performance will be lower (Cerezo, Sánchez-Santillán, Paule-Ruiz, \& Núñez, 2016).

Relevant studies in the literature show that the interaction of students with online assignments affects learning outcomes regarding blended learning. In addition, it is recommended that students' assignment submitting behaviors are handled within the framework of learning analytics and examined in detail (Bayrak, 2018; Cerezo et al., 2017; You, 2016). When the relevant literature is examined; It is determined that there is a very limited number of studies focusing on online assignment submitting process regarding blended learning and modeling assignment submitting behaviors in the scope of authentic learning process. Therefore, in this study, it is purposed to investigate the relationship between the students' assignment submission behaviors and course achievement in the scope of blended learning.

For this purpose, students' assignment submission logs in Moodle environment are converted to time series format by applying some data transformation algorithms, and then students who followed a similar assignment submitting pattern are grouped using cluster analysis. The assignment submission processes and the academic performances of the students in different clusters are also analyzed. Within the scope of the research, answers to the three questions below are sought.

1. Can students exhibiting similar assignment submission behavior be determined by analyzing log records?

2. What kind of differences are there among students who have different assignment submission behavior?

3. Is there a significant relationship between assignment submission behavior and students' course achievement?

It is hoped that the results of the present study would provide insight into understanding students' assignment submission process and early identification of students at risk of failing the course. In addition, it is aimed to figure out useful suggestions for online learning design in the scope of blended learning. Analyzing assignment submission behaviors based on learning analytics and modeling the related behaviors using the process mining technique is what makes the study different from the others.

\section{Methodology}

This study is an educational data mining study in which interaction data based on students' assignmentsubmission behaviors are modeled and associated with course achievement. The steps that are followed and the data analysis process are explained in detail. 


\subsection{Participants and Data Collection Process}

75 students enrolled in the Operating Systems course, studying at the Department of Computer Education and Instructional Technologies at a public university participated in the study. In addition to face-to-face lessons, the Moodle online learning environment is actively used as part of the lesson. The activities of students in Moodle environment can be summarized as, following the course resources, participating in the discussions, doing assignments. The role of the Moodle system in the course is explained to the students at the beginning of the semester and it is stated that their assignment on this system would be $25 \%$ part of their final score. The assignments consist of open-ended questions related to the subject that will be taught that week. The questions are prepared by the instructor to reflect the students' knowledge level on the subject and enable them to analyze and report the information they compiled from different sources. Assignments are uploaded to the system within 1-2 days following the course and students are given 5-6 days to complete the assignments. The starting time of the lesson is set as the deadline for the assignment of the last week. Students are not allowed to send late. The assignments are evaluated by the instructor and the scores of the students are announced on the system. During the semester, 10 assignments with different properties are given to the students, and the data related to the assignment given to the students in the $4^{\text {th }}$ week are analyzed. This assignment is chosen because of the fact being the first comprehensive assignment of the period.

\subsection{Data Pre-Processing}

The data of six students who did not take the final exam are excluded from the analysis. Eight students who did not have any log records related to the assignment but entered the final exam are included in the study. A total of 2928 line log data for 69 students are analyzed. All activities that students can perform regarding an assignment are presented in Table 1. The log sequence for a student can include all these activities, or only one or several. Also, each case can take place more than once in a log sequence. Among the examined records, the shortest log sequence contains only one record, while the longest log sequence consists of 268 records. While an average log consists of 48 records, the median value is 41 . An example log sequence consisting of 14 records of a student can be as in the following; Assignment viewed $\rightarrow$ Attempt started $\rightarrow$ Question viewed $\rightarrow$ Question viewed $\rightarrow$ Question viewed $\rightarrow$ Question viewed $\rightarrow$ Question viewed $\rightarrow$ Question viewed $\rightarrow>$ Assignment submitted -> Assignment viewed -> Question reviewed-> Question reviewed-> Question reviewed-> Question reviewed. During the data pre-processing, Moodle $\log$ records are processed and the activities carried out by each student regarding the assignment are recorded sequentially in the analysis file. In this process, transitions less than three seconds between them are eliminated to standardize the records.

Table 1. Activities that the students can perform in the assignment submission process

\begin{tabular}{ll}
\hline Activity & Description \\
\hline Assignment viewed & $\begin{array}{l}\text { The student viewed the assignment module, saw the assignment description, but } \\
\text { did not open the questions. } \\
\text { This is only the case when the student views the assignment for the first time, } \\
\text { this does not happen again on subsequent visits. } \\
\text { The student's displaying each question in the assignment is logged in this way. } \\
\text { Question viewed } \\
\begin{array}{l}\text { Displaying the question also means recording the text in the answer field. } \\
\text { This happens when the student completes the assignment. The student can } \\
\text { Assignment submitted }\end{array} \\
\text { Submit the assignment once and, then cannot change the answers. } \\
\text { If the student displays the assignment after the deadline, it will be labeled as a } \\
\text { review. At this stage, the student can view the answer s/he gave or see the grade } \\
\text { if the assignment is graded. }\end{array}$ \\
\hline
\end{tabular}

Log activities for all students are presented visually in Figure 1. As can be seen, students followed different patterns in the process of submitting assignments. Some students spent a lot more time in the process of submitting assignment, whereas others seem to have completed this process quickly. Likewise, some students checked their responses after submission, while others did not reopen the assignment after submission. It is seen that some students did not view the assignment and answer the questions, did not submit the assignment. 


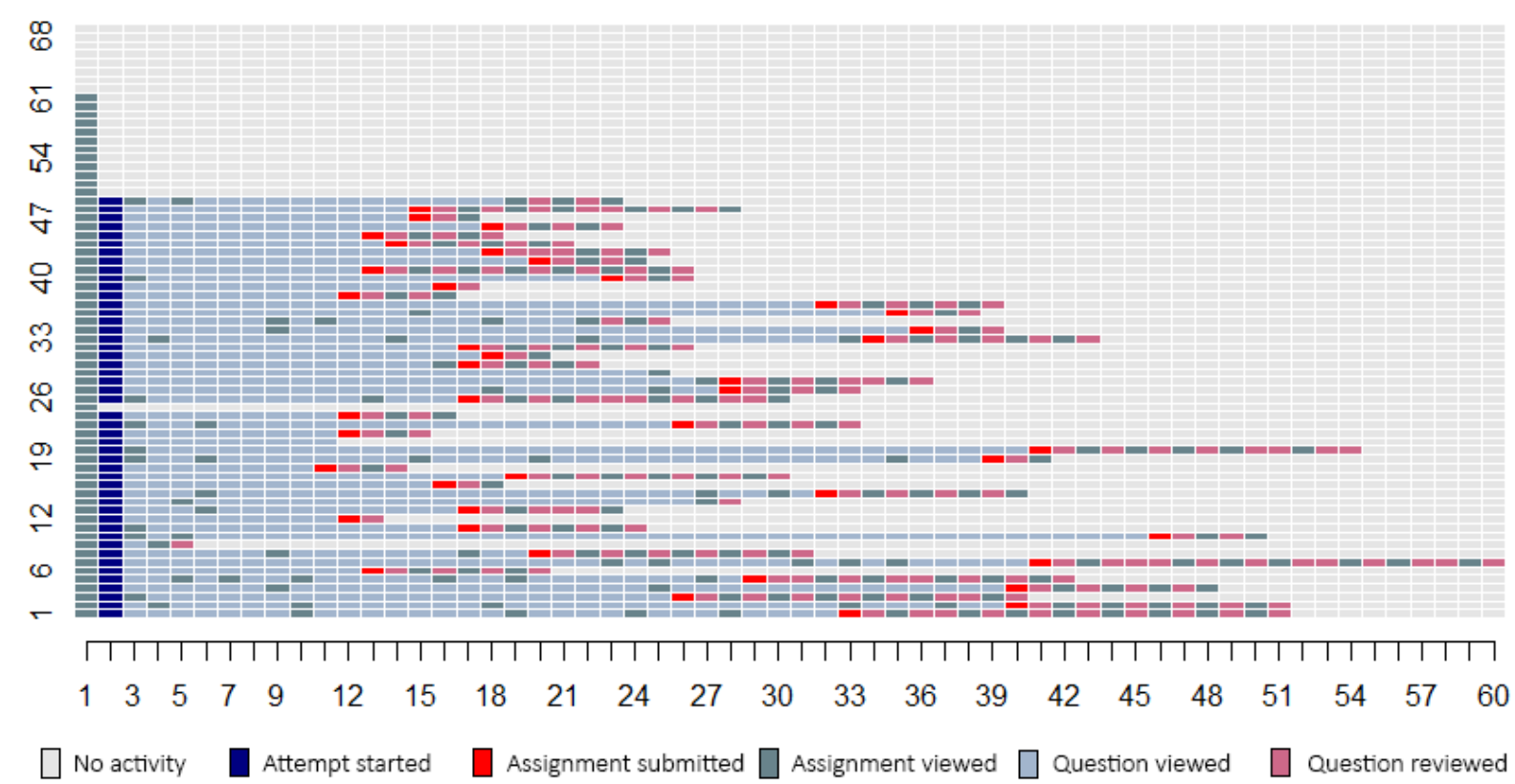

Figure 1. Visual presentation of students' assignment submissions behaviors

\subsection{Data Analysis}

Data analysis is carried out with the $\mathrm{R}$ programming language ( $\mathrm{R}$ Core Team, 2017). Visualization and analysis of sequential data are performed through the package TraMineR (Gabadinho, Ritschard, Müller, \& Studer, 2011). Ward distance criterion is used to group similar students. Ward distances are visualized as dendrogram to decide the number of clusters. The assignment submission processes of the students in different clusters are analyzed by process mining analysis. One-way analysis of variance (ANOVA) analysis is conducted to examine whether there are any differences in terms of academic performance of students in different clusters.

\section{Results}

\subsection{Cluster Analysis}

According to the cluster analysis results presented in Figure 2, it is seen that the students can be divided into two, three or five groups according to their assignment submission data. When Ward distance measurement is taken into account, it is decided that three clusters are suitable for this data set.

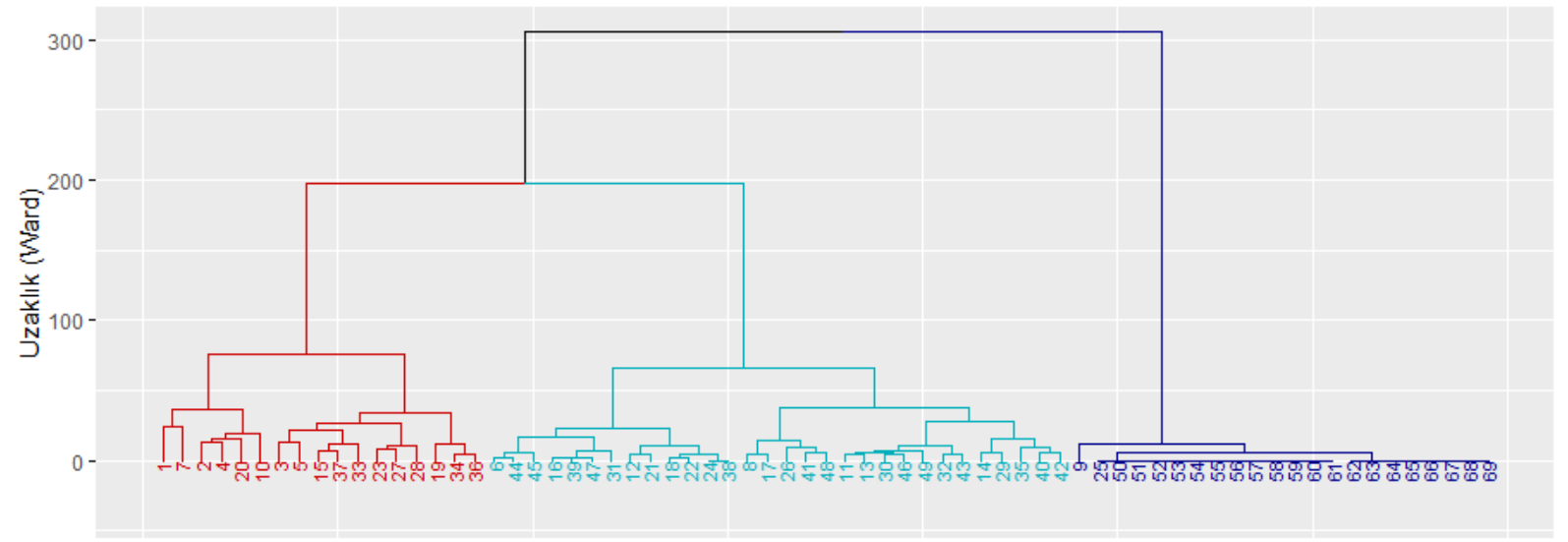

Figure 2. Results of cluster analysis

Assignment submission behaviors of students in each cluster are presented visually in Figure 3. According to this; while the students who submit their assignment are grouped in Cluster 1 or Cluster 2, it is seen that the Cluster 3 consists of students who have never viewed the assignment or have viewed it but did not submit it. When the submission behaviors of students in Cluster 1 and Cluster 2 are analyzed, it is seen that the students in Cluster 1 have more visits between questions and string the submission out by displaying the assignment more than once instead of completing the assignment in a single session. Students in Cluster 2 completed the 
assignment in fewer steps, but an important part of it completed the assignment in a single session. When the review behaviors after submitting the assignment are examined, it is seen that the students in both groups checked the grading done by the instructor by viewing the assignment after the submission is completed and looked at the feedback, if any.
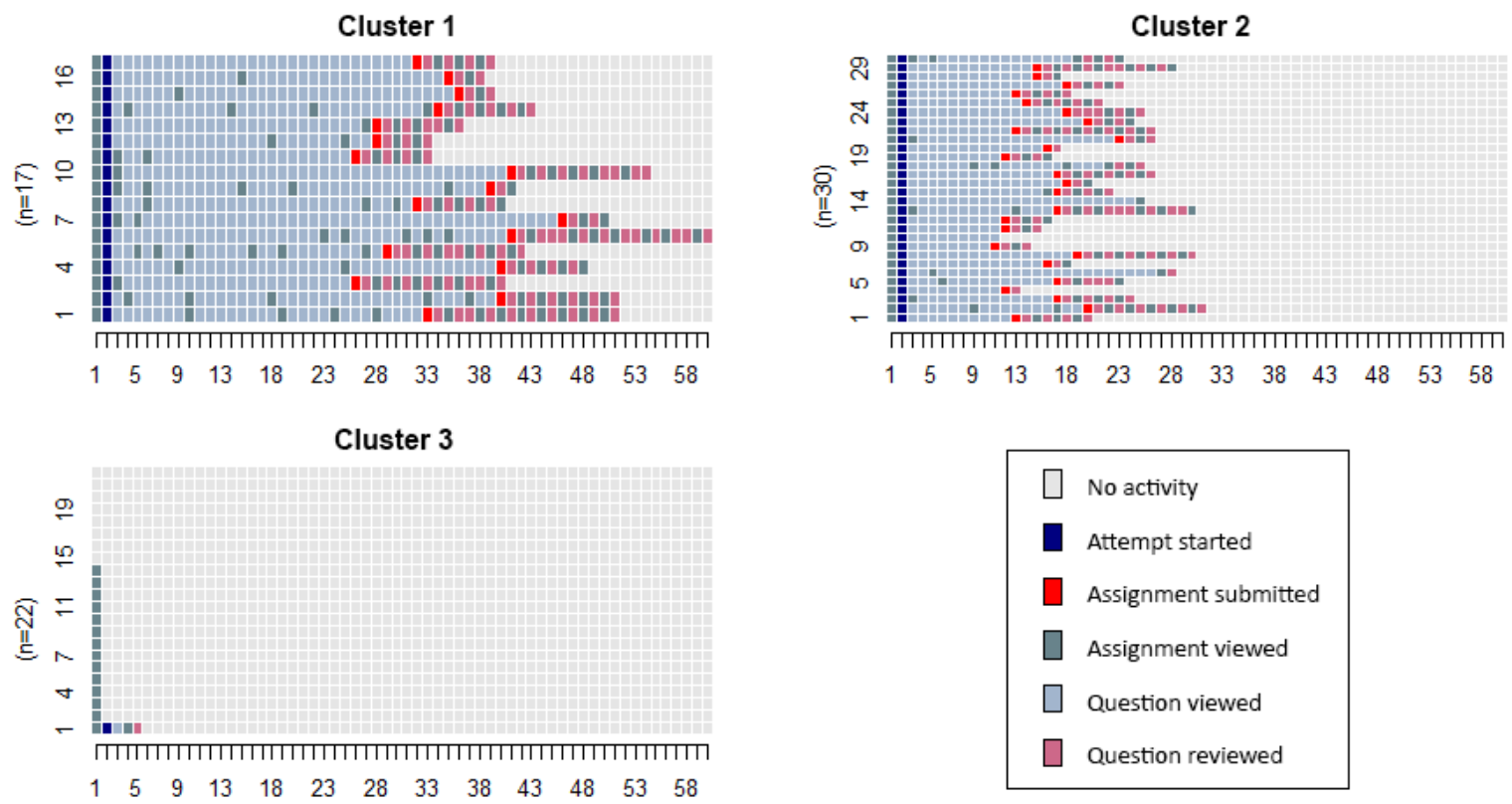

Figure 3. Assignment submission behaviors of students in each cluster

\subsection{Modelling the Process of Students' Assignment Submission}

The assignment consists of sub questions and each question is on a different page. Each page view of the assignment module is recorded as Assignment viewed. The student's displaying of the assignment does not mean opening the assignment. Therefore, a student who displayed the assignment is supposed to start submitting first of all to see the questions. Then, s/he can navigate between the questions. This step is recorded as Question viewed. As long as the assignment deadline is not over, the student can leave this stage and continue at any time. The answers written are automatically recorded during the navigation between the questions, so there is not an extra saving event. After the student completes the assignment, s/he should submit the assignment before the deadline. This step is recorded as Assignment submitted. After the submission, a student can display the assignment again at any time and review the answers given to the questions, after the assignment is scored by the instructor, a student can see the score s/he has got from each question and read the feedback that the instructor has written for each question. After the assignment is submitted, viewing each question is recorded as Question reviewed. Attempt started and Assignment submitted steps, which are the steps of the process, are one-time situations for each student. The steps namely Assignment viewed, Question viewed and Question reviewed can be taken place for several times.

The assignment submission process of the students in the Cluster 1 and Cluster 2 are examined through process mining analysis and the results are presented in Figure 4. When results are analyzed, two patterns come to the forefront; one related to the submission process and one related to the review process. The pattern regarding the assignment submission process as in the following: Assignment viewed -> Attempt started -> Question viewed (again) -> Assignment submitted. The pattern regarding the review process: Assignment viewed -> Question reviewed. In addition to these two patterns, another pattern emerging in the first cluster is Assignment viewed -> Question viewed (again). This situation can be interpreted as that the students in the first cluster submit their assignment in more than one session, and the students in the second cluster submit at once. 


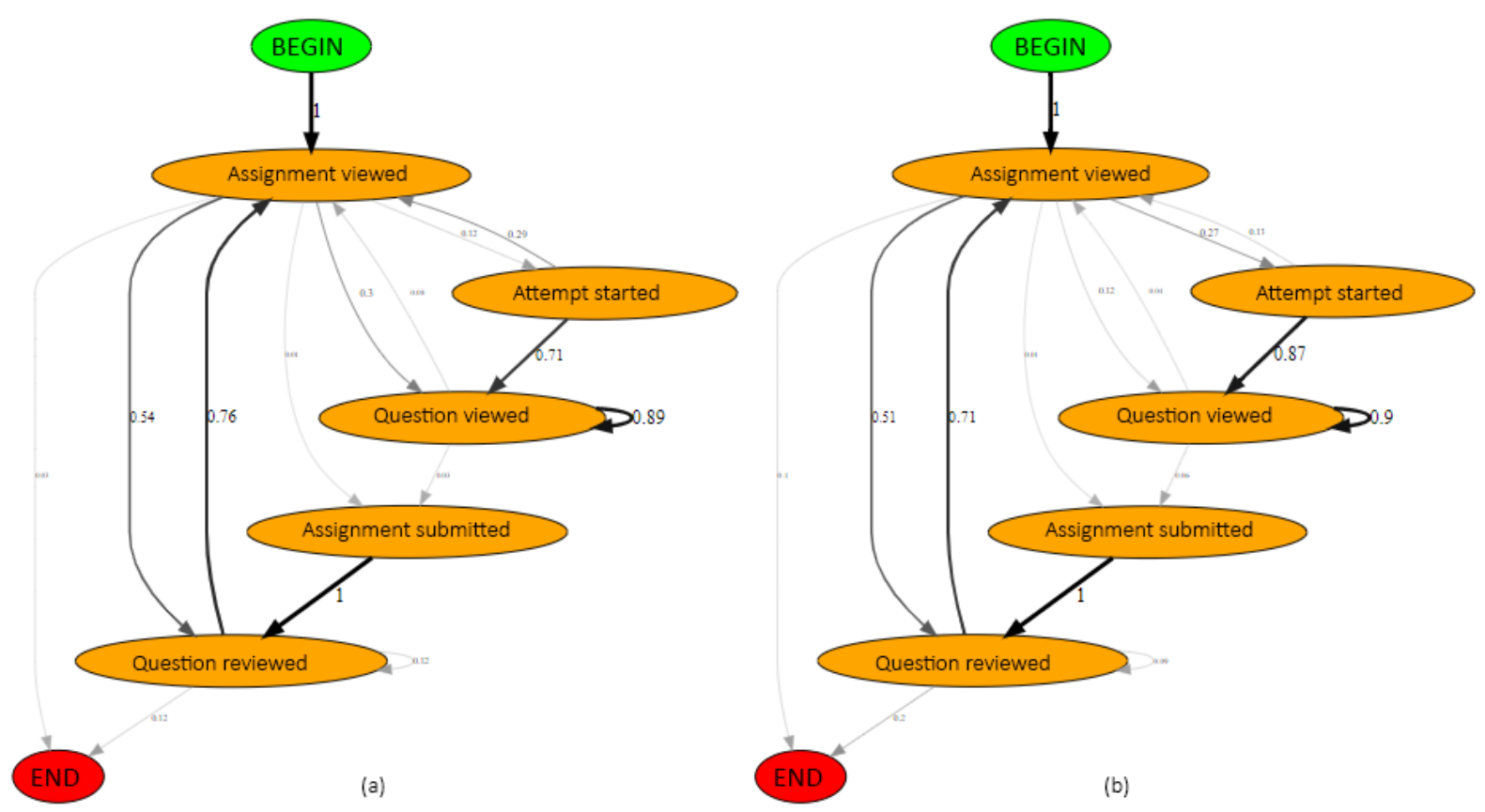

Figure 4. The models of students' assignment submission process in Cluster 1 (a) and Cluster 2 (b)

\subsection{Examination of the Relationship Between Submission of Assignment and Course Achievement}

Descriptive statistics on the academic performance of students in each cluster are presented in Table 2.

Table 2. Descriptive statistics

\begin{tabular}{lccc}
\hline Cluster & The Number of Students & Mean & Standard Deviation \\
\hline Cluster 1 & 17 & 65.5 & 11.5 \\
Cluster 2 & 30 & 60.2 & 15.2 \\
Cluster 3 & 22 & 41.8 & 13.0 \\
\hline
\end{tabular}

The academic performance of the students at the end of the semester is determined by considering the midterm, a final exam and the grades they have got from the assignments submitted during the term. One-way ANOVA analysis was carried out to examine whether students in different clusters differ in terms of their academic performance at the end of the semester. ANOVA results are shown in Table 3. Normality was tested with Kruskal-Wallis analysis and the equality of variances was tested with Levene analysis and it is seen that the assumptions are met.

Table 3. Comparison of End-of-Term Academic Performance of Students Displaying Different Assignment Submission Behaviors with One-Way ANOVA

\begin{tabular}{lcccccc}
\hline & Sum of Squares & $\begin{array}{c}\text { Degrees of } \\
\text { Freedom }\end{array}$ & Mean Squares & F & p & $\begin{array}{c}\text { Effect } \\
\text { Size }\end{array}$ \\
\hline Between Group & 6479 & 2 & 3240 & 17.27 & $<0.001$ & 0.343 \\
Within Group & 12380 & 66 & 188 & & & \\
Total & 18859 & 68 & & & & \\
\hline
\end{tabular}

When the results presented in Table 3 are analyzed, it is seen that there is a significant difference between the clusters in terms of average course success $[\mathrm{F}(2.66)=17.27, \mathrm{p}<0.001$, effect size $=0.343$ ] . Post-hoc analyzes were carried out using the Tukey test to determine which groups are different from each other's. According to the Tukey test results, it is observed that there is no significant difference between Cluster 1 and Cluster 2 in terms of average course success ( $p>0.1$ ), on the other hand, there is a significant difference between Cluster 1 and Cluster 3 ( $\mathrm{p}<0.001)$ and between Cluster 2 and Cluster $3(\mathrm{p}<0.001)$. In other words, students in Cluster 1 got a score with an average of 23.7 points higher than students in Cluster 3; Students in Cluster 2 got score with an average of 18.4 points higher than students in Cluster 3. Students in Cluster 1 got a score with an average of 5.3 points higher than students in Cluster 2, but this difference is not considered as statistically significant.

\section{Discussion and Conclusion}

In this study, cluster analysis and process mining analysis are used to analyze the assignment submission behavior of the students in the Moodle learning management system. Assignment submission behaviors are 
obtained based on students' interaction data in an authentic learning context. Students are profiled based upon their assignment submissions behaviors, and submission behaviors related to explored profiles are modeled with process mining. In addition, it is analyzed whether there is a difference between the course successes of the students who exhibit different assignment submission behaviors.

As a conclusion of the study, it is found that students are clustered in three groups according to their assignment submission behavior. Two of these groups consisted of students who completed the assignment, while one group consisted of entire students who did not submit the assignment. The process mining analysis enabled to compare the two groups that submit assignments in more detail. Accordingly, it is observed that there is a similarity between the students in Cluster 1 and Cluster 2 to submit their assignments, but there are also some differences. Unlike the others, it is observed that students in Cluster 1 submitted their assignments in more than one session. This result shows that students' assignment submission behaviors differ from each other and some students invest in more time with their assignment pages. In the study by Kovanovic et al. (2015), it is concluded that the academic performance of students increased based on their efforts in performing their learning tasks. In this study, it is found that there is no significant difference in the course success of the student groups who sent their assignment on time but who differed in their assignment behaviors. For this reason, in future studies, new modeling studies can be conducted by taking into consideration the time dimension.

The end-of-year achievements of students with different assignment submission behaviors showed that $86 \%$ of the students in the $3^{\text {rd }}$ Cluster that did not submit the assignment fail the course; on the other hand, it is observed that $88 \%$ of students in Cluster 1 who submitted the assignment and $67 \%$ of students in Cluster 2 were successful in the course. Similar to this finding, in the study conducted by Zacharis (2015), in a blended learning environment supported by the Moodle learning management system, it is shown that students with a small number of assignment submissions are more likely to fail. In addition, this finding is found to be consistent with the relevant study findings, which reveal that assignment and interaction data are significant in predicting student's achievement (Kovanovic et al., 2015; MacFadyen \& Dawson, 2010). The findings that the students' who are in the Cluster 3 and did not submit their assignment, have underachievement; supports the findings that the students' failure to submit their assignment is an indicator of academic procrastination and that the mentioned students have underachievement (Cerezo et al., 2017; You, 2015, 2016). Therefore, according to this finding, it may be suggested to provide automatic interventions and instant feedback to increase learner interaction with online assignments in order to increase learner success in the blended learning process. In addition, it can be stated that data on students' assignment submission behaviors should be taken into consideration in learning analytics dashboards.

The findings can be used to determine the students who will fail at the end of the semester in the first weeks of the course. Interventions at this stage can be effective in preventing students' possible failures. Studies demonstrate that the students' end-of-year performances can be predicted accurately from the first weeks of the course (Akçapınar, Altun, \& Aşkar, 2019). It is fundamental to design and test interventions especially for students who are likely to fail the course in future studies. In this study, the data related to the assignment given to the students in the fourth week of the course were analyzed. This assignment was selected because it was the first comprehensive assignment of the course. This is one of the limitations of the study. In future studies, it can be examined whether the behavior patterns of the students change based on the difficulty level of the assignments and individual differences of students.

Ethics Committee Approval Information: Ethics committee approval for this research was obtained from Trabzon University, Social and Humanities Ethics Committee, with the date 5 March 2020 and document number 81614018-000.E109. 


\section{Üniversite Öğrencilerinin Ödev Gönderme Davranışları ile Ders Başarıları Arasındaki İlişkinin Süreç Madenciliği Analizi ile İncelenmesi}

\section{Giriş}

Öğrencilerin çevrimiçi öğrenme ortamlarında gerçekleştirdikleri etkileşimler sonucu geride bıraktıkları öğrenme izleri (log kayıtları), öğrencilerin öğrenme süreçlerinin anlaşılması konusunda araştırmacılara yol göstermektedir. Bu ortamlardan elde edilen veriler, makine öğrenmesi yöntemleri ile analiz edilerek öğrencilerin akademik başarılarından, derse hazırlanırken izledikleri stratejilerin belirlenmesine kadar farklı amaçlarla kullanılmaktadır. Alanyazında öğrenme analitikleri, eğitsel veri madenciliği, eğitimde yapay zekâ uygulamaları gibi başlıklar altında toplanan bu çalışmalara araștırmacıların ilgisi son yıllarda giderek artmaktadır. Çünkü ilgili araştırmalarda hem çevrimiçi öğrenmeye hem de çevrimiçi öğrenme ile desteklenen diğer öğrenme modelleri için önemli, işevuruk çıktılar üretilmektedir. Benzer yaklaşımla bu çalışmada, üniversite öğrencilerinin ödev gönderme davranışlarının eğitsel veri madenciliği yöntemlerinden birisi olan süreç madenciliği yöntemi işe koşularak modellenmesi ve ortaya çıkarılan profiller ile öğrencilerin ders başarıları arasındaki ilişkinin incelenmesi amaçlanmıştır.

\subsection{Karma Öğrenme Bağlamında Çevrimiçi Öğrenme Deneyimleri}

Çevrimiçi öğrenme etkinlikleri ile desteklenen karma öğrenme ortamları, öğrencilerin öğrenme süreçlerine önemli ölçüde destek olmaktadır. Yükseköğretim düzeyinde yüz yüze işlenen derslerin çevrimiçi öğrenme ortamları ile desteklenmesi, öğrenciler ve öğretim elemanları için yüz yüze öğrenme bağlamına kıyasla daha esnek bir öğrenme olanağ1 sunmaktadır (Graham, 2006; Symth, Houhton, Cooney ve Casey, 2012). Bu noktada önemli olan, bireysel farklılıklar da göz önünde bulundurularak karma öğrenme sürecinde etkili öğrenme deneyimlerinin nasıl ortaya çıktığının belirlenmesi ve elde edilen işevuruk sonuçların öğrenme tasarımı bağlamında kullanılmasıdır.

Öğrencilerin bireysel özelliklerinin ve çevrimiçi öğrenme deneyimlerinin ders başarısı ve öğrenme çıktıları üzerinde önemli derecede etkili olduğu, çalışma sonuçlarına yansımaktadır. İlgili alanyazındaki bazı çalışmalar; öğrencilerin öz yeterlik, öz düzenleme becerileri, akademik ertelemecilik, teknoloji okuryazarlığı, kontrol odağ gibi bireysel özelliklerinin karma öğrenmenin etkililiği üzerinde anlamlı rolü olduğunu göstermektedir (Broadbent, 2017; Prasad, Maag, Redestowics ve Hoe, 2018; Rasheed, Kamsin ve Abdullah, 2020). Bu bağlamda öğrencilerin bireysel özelliklerine göre öğrenme tasarımının gerçekleştirilmesinin, karma öğrenmede etkileşimi ve esnekliği artırdığı ve öğrenme sürecinin daha verimli olmasını sağladığı vurgulanmaktadır (Porter, Graham, Spring ve Welch, 2014). Bununla birlikte karma öğrenmenin etkili olabilmesi için öğrencilerin çevrimiçi öğrenme deneyimlerinin objektif verilere dayalı olarak derinlemesine anlaşılması gerekmektedir (Kokoç ve Altun, 2019).

Öğrenme analitikleri verilerinin incelenmesi; karma öğrenme sürecinde öğrencilerin çevrimiçi öğrenme deneyimlerinin derinlemesine anlaşılması ve öğrencilerin karma öğrenme performansının tahmin edilmesi açısından oldukça önemlidir. Bu bağlamda ilgili alanyazında, karma öğrenmede öğrenme çıktılarını öğrenme analitikleri verilerine dayalı olarak yordamayı amaçlayan çalışmalar gerçekleştirilmiştir. Zacharis (2015), karma öğrenme yoluyla gerçekleştirilen bir programlama dili dersi bağlamında öğrencilerin öğrenme analitikleri verilerinin dönem sonu başarılarının yordayıp yordamadığını incelemiştir. Moodle öğrenme yönetim sistemi üzerindeki etkileşimlere dayalı olarak üretilen 29 değişkenden 14'ünün öğrencilerin final notlarını yordamada anlamlı olduğunu, dört etkileşim değişkenin (mesajları okuma ve gönderme, içerik oluşturmaya katkı, sınav çabaları ve görüntülenen dosya sayısı) ise final notlarındaki varyansın \%52'sini açıkladığı belirlenmiştir. Jo, Park, Kim ve Song (2014) tarafından yürütülen bir çalışmada, öğrencilerin çevrimiçi davranışlarının karma öğrenme ortamlarında öğrenme performansını yordamada etkili olup olmadığ 1 incelenmiştir. Çalışma kapsamında öğrenme yönetim sistemi destekli iki ayrı karma öğrenme dersinden toplanan veriler işlenmiştir. Analiz sonucunda ortaya çıkan regresyon modelinin, öğrencilerin çevrimiçi öğrenme davranışlarını yansıtan etkileşim verilerinin öğrenme performansındaki varyansın \%70'ini anlamlı bir şekilde yordayabildiğini göstermiştir. Bir diğer çalışmada ise karma öğrenme yoluyla yürütülen bir Bilgisayar Donanımı dersinde öğrenme analitikleri verileri kullanılarak riskli öğrencilerin akademik performanslarını tahmin etmeyi amaçlayan bir erken uyarı sistemi geliştirilmiştir (Akçapınar, Altun ve Aşkar, 2019). Farklı sınıflama algoritmalarının işe koşulduğu çalışma sonucunda; öğrencilerin etkileşim verilerine dayalı olarak oluşturulan tahmin modellerinin, henüz dersin üçüncü haftasında başarısız öğrencileri anlamlı bir şekilde tahmin edebildiği ortaya koyulmuştur. Lu ve diğerleri (2018) tarafından yapılan çalışmada, diğer çalışmalardan farklı olarak, karma öğrenme bağlamında öğrenci performansını tahmin etmede hem yüz yüze hem de çevrimiçi öğrenme ortamındaki öğrenci verilerinin istatistiksel açıdan anlamlı rol oynadığı belirlenmiştir. İlgili çalışmaların sonuçları, öğrencilerin çevrimiçi öğrenme deneyimlerinden elde edilen etkileşim verilerinin, karma öğrenme bağlamında öğrenci performansını tahmin etmede etkili olduğunu kanıtlamaktadır. 
Karma öğrenme bağlamında öğrencilerin çevrimiçi öğrenme deneyimleri, öğrenme sürecinde kendilerine sunulan öğrenme kaynakları, etkinlikler ve görevleri ile ilişkilidir. Kokoç ve Altun (2019), öğrencilerin çevrimiçi etkileşim verilerinin altı faktör altında toplandığı ve bu faktörlerin öğrencilerin öğrenme deneyimlerini yansıttığını ortaya koymuştur. Çevrimiçi ödevler, etkili çevrimiçi öğrenme deneyimlerinin ortaya çıkışında oldukça önemli rol oynayan öğrenme etkinliklerinden biridir. Dolayısıyla öğrenme analitikleri bağlamında öğrencilerin çevrimiçi ödevler ve öğrenme görevleri ile etkileşiminin ele alınması, öğrenme deneyimlerinin daha iyi anlaşılması için yararlı olacaktır.

\section{2. Çevrimiçi Ödevler ve Öğrenme Analitikleri Çalışmaları}

Ödevler, öğrenme sürecinin etkililiğini snnamak amacıyla sıklıkla kullanılan bir öğrenme etkinliğidir. Çevrimiçi öğrenmenin doğası gereği, öğrencilerin kendi öğrenme süreçlerinden daha fazla sorumlu olmaları beklenmektedir (Dabbagh ve Kitsantas, 2005). Dolayısıyla çevrimiçi öğrenme görevlerinin sorumluluğunu yerine getiren ve öğrenme görevlerinin düzenli olarak tamamlayan öğrenciler, başarılı öğrenciler olarak tanımlanmaktadır (You, 2016). En az bir çevrimiçi ödev tamamlayıp yükleyen öğrencilerin uzaktan eğitim derslerini başarıyla tamamlama olasılıklarının daha yüksek olduğu bilinmektedir (Lim, 2016). Bu noktada ödev tamamlama sayısının ötesinde, öğrencilerin çevrimiçi ödevlerle ve öğrenme görevleriyle ilgili sayfalarla etkileşimlerinin nasıl olduğu sorusu akla gelmektedir.

Ödevler ile etkileşim verileri, genellikle öğrencilerin öğrenme görevleriyle ilgili hazırladıkları ödev dosyaların yükleme sayılarına, ödevlerle ilgili sayfalarda geçirdikleri süreye, öğretim elemanları tarafindan sağlanan ödev geribildirimlerini inceleme sıklığ 1 ve sürelerine karşılık gelmektedir. Öğrenme analitikleri alanyazınında öğrencilerin ödevler ile etkileşimlerinin öğrenme performanslarıyla ilişkisine dönük sınırlı sayıda da olsa çalışmaların olduğu görülmektedir. MacFadyen ve Dawson (2010) tarafindan gerçekleştirilen çalışmada, öğrencilerin akademik performansları ile etkileşim verileri arasındaki ilişki, lojistik regresyon analizi kullanılarak incelenmiştir. Tamamlanan çevrimiçi ödev sayısının, öğrencilerin dönem sonu başarılarını tahmin eden önemli değişkenlerden biri olduğu sonucuna ulaşılmıştır. Moodle öğrenme yönetim sistemi destekli bir karma öğrenme süreci bağlamında gerçekleştirilen bir çalışmada ise öğrencilerin ödev yükleme sayılarının öğrencilerin final notlarını anlamlı bir şekilde yordadığı bulunmuştur (Zacharis, 2015). Bununla birlikte karma öğrenme ortamlarında öğrenci başarısını tahmin etmeyi amaçlayan bazı çalışmalarda, öğrencilerin haftalık çevrimiçi ödevlerden aldıkları puanların öğrenme performansının anlamlı bir yordayıcısı olduğu belirlenmiştir (Huang ve Fang, 2013; Lu ve diğerleri, 2018). Diğer bir çalışmada, öğrencilerin öğrenme görevlerini yerine getirirken sergiledikleri çabalarına dayalı olarak akademik performanslarının tahmin edilmesi amaçlanmıştır (Kovanovic ve diğerleri, 2015). Kurulan farklı regresyon modellerinden elde edilen bulgular, öğrencilerin ödev sayfalarını görüntüleme sıklığının ve ödevlere harcadığı zamanın akademik performanslarını tahmin etmede etkili olduğunu göstermiştir. Dolayısıyla ilgili araştırmaların sonuçları, karma öğrenme ortamlarında öğrencilerin öğrenme görevleri ve ödevler ile ilgili etkileşimlerinin etkili çevrimiçi öğrenme deneyimlerinin oluşturulmasında anlamlı rol oynadığını işaret etmektedir.

Karma öğrenme bağlamında öğrencilerin ödev gönderme davranışlarının önemini gösteren çalışmalardan bir kısmı da akademik ertelemecilikle ilgilidir. Öğrencilerin ödevlerini geç göndermeleri veya göndermemeleri ve eşzamanlı olarak ödevler üzerinde grup olarak veya bireysel gösterilen çaba gibi değişkenler ile akademik ertelemecilik ilişkilendirilmektedir. Her ne kadar karma öğrenme bağlamında yürütülen bir çalı̧̧mada, öğrencilerin akademik görevleri erteleme eğilimleri ve etkinlik gönderme süreleri arasında anlamlı bir ilişki olmadığı bulunmuş olsa da (Bayrak, 2018), öğrenme analitikleri çalışmalarında ödev gönderme davranışlarının akademik ertelemeciliğin önemli bir göstergesi olduğu ve ders başarısını etkilediği vurgulanmaktadır. Bu konuda yapılmış çalışmalardan biri, karma öğrenme bağlamında öğrencilerin etkileşim ve ertelemecilik davranışlarını inceleyerek öğrenme performansları ile birlikte modellemeyi amaçlamıştır (Cerezo, Esteban, Sánchez-Santillán ve Núñez, 2017). İlgili çalışmada, öğrencilerin haftalık ödevlerini kontrol etmek için bekledikleri gün sayısı, ertelemecilikle ilişkili etkileşim değişkeni olarak ele alınmıştır. Birliktelik kuralları algoritmalarının işe koşulduğu çalışmada yüksek güven oranıyla ortaya konulan kurallar, geç ödev gönderimi yapan öğrencilerin akademik performansının daha düşük olacağına işaret etmektedir. You $(2015,2016)$ tarafindan yürütülen çalışmalarda da, ödevlerin geç gönderilmesinin veya gönderilmemesinin öğrencilerin ders başarı notları ve sınav puanları üzerinde anlamlı olumsuz etkiye sahip olduğu sonucuna ulaşılmıştır. İlgili çalışmada, ödev gönderme davranışları akademik ertelemeciliğin göstergesi olarak kabul edilmiştir. Benzer nitelikteki diğer çalışmalarda ise öğrencilerin ödevlerini yükleyene kadar geçen süre azaldıkça öğrenme performansının daha yüksek olacağ 1 (Paule-Ruiz, Riestra-Gonzalez, Sánchez-Santillan ve Pérez-Pérez, 2015), öğrencilerin öğrenme görevlerini geç yerine getirmesinin ve ödevlerin teslim edilmesi için geçen sürenin artmasının öğrenme performanslarının düşürdüğü sonuçlarına ulaşılmıştır (Cerezo, Sánchez-Santillán, Paule-Ruiz ve Núñez, 2016).

Alanyazındaki ilgili çalışmalar, öğrencilerin çevrimiçi ödevler ile etkileşiminin karma öğrenme bağlamında öğrenme çıktılarını etkilediğini göstermektedir. Bununla birlikte öğrencilerin ödev gönderme davranışlarının öğrenme analitikleri çerçevesinde ele alınması ve detaylı olarak incelenmesi önerilmektedir (Bayrak, 2018; Cerezo ve diğerleri, 2017; You, 2016). İlgili alanyazın incelendiğinde; karma öğrenme bağlamında çevrimiçi 
ödev gönderme davranışlarına odaklanan ve otantik öğrenme süreci bağlamında ödev gönderme davranışlarını modelleyen çalışmaların oldukça sınırlı sayıda olduğu belirlenmiştir. Dolayısıyla bu çalışmada, karma öğrenme bağlamında üniversite öğrencilerinin ödev gönderme davranışları ile ders başarıları arasındaki ilişkinin incelenmesi amaçlanmıştır.

$\mathrm{Bu}$ amaçla öğrencilerin Moodle ortamındaki ödev gönderme logları bir takım veri dönüştürme algoritmaları uygulanarak zaman serisi formatına dönüştürülmüş, daha sonra kümeleme analizi kullanılarak benzer ödev gönderme örüntüsü izleyen öğrenciler gruplanmıştır. Farklı kümelerde yer alan öğrencilerin ödev gönderme süreçleri ve derste sergiledikleri akademik performansları da analiz edilmiştir. Araştırma kapsamında aşağıda verilen üç temel soruya cevap aranmıştır.

1. Benzer ödev gönderme davranışı sergileyen öğrenciler, log kayıtları analiz edilerek belirlenebilir mi?

2. Farklı ödev gönderme davranışı sergileyen öğrencilerin ödev gönderme süreçlerinde ne tür farklılıklar vardır?

3. Ödev gönderme davranışı ile öğrencilerin ders başarıları arasında anlamlı bir ilişki var mıdır?

Araştırmadan elde edilecek bulgular, öğrencilerin ödev gönderme davranışlarının anlaşılması ve dersten başarısız olma riski yüksek olan öğrencilerin erkenden belirlenmesi konusunda bilgiler sağlayacaktır. Ek olarak, karma öğrenme bağlamında çevrimiçi öğrenme tasarımı için işe vuruk önerilerin ortaya çıkarılması hedeflenmektedir. Ödev gönderim davranışlarının objektif türde öğrenme analitikleri verilerine dayalı olması ve ilgili davranışların süreç madenciliği tekniği kullanılarak modellenmesi, çalışmayı özgün kılmaktadır.

\section{Yöntem}

$\mathrm{Bu}$ çalışma, öğrencilerin ödev gönderme davranışlarına dayalı etkileşim verilerinin (öğrenme analitikleri verilerinin) modellendiği ve ders başarısı ile ilişkilendirildiği bir eğitsel veri madenciliği çalışmasıdır. Çalışma kapsamında takip edilen aşamalar ve veri analizi süreci, ayrı başlıklar altında detaylı olarak açıklanmıştır.

\subsection{Katılımcılar ve Veri Toplama Süreci}

Araştırmaya bir devlet üniversitesinde Bilgisayar ve Öğretim Teknolojileri Eğitimi Bölümü’nde eğitim gören, İşletim Sistemleri dersine kayıtlı 75 öğrenci katılmıştır. Ders kapsamında yüz yüze derslere ek olarak Moodle çevrimiçi öğrenme ortamı aktif olarak kullanılmıştır. Öğrencilerin Moodle ortamında gerçekleştirdikleri başlıca aktiviteler; ders kaynaklarını takip etme, ders ile ilgili tartışmalara katılma, verilen ödevleri yapma şeklindedir. Öğrencilere dönem başında Moodle sisteminin dersteki rolü anlatılmış, bu sistem üzerinden yaptıkları ödevlerin dönem sonu başarıları üzerinde \%25 etkisi olacağı ifade edilmiştir. Verilen ödevler o hafta ele alınacak olan konuyla ilişkili açık uçlu sorulardan oluşmaktadır. Sorular, öğrencilerin konuya ilişkin bilgi düzeylerini yansıtacak ve farklı kaynaklardan derledikleri bilgileri analiz edip raporlamalarını sağlayacak şekilde ders sorumlusu tarafından hazırlanmıştır. Ödevler, dersi takip eden bir, iki gün içerisinde sisteme yüklenmiş ve öğrencilere ödevleri tamamlamaları için beş, altı günlük bir süre verilmiştir. Dersin başlama saati bir önceki hafta verilen ödev için son gönderim zamanı olarak ayarlanmıştır. Öğrencilerin geç gönderim yapmasına ise izin verilmemiştir. Ödevler ders sorumlusu tarafından değerlendirilerek öğrencilerin aldıkları puanlar sistem üzerinden duyurulmuştur. Öğrencilere dönem süresince farklı özelliklerde 10 adet ödev verilmiştir, çalışma kapsamında ise öğrencilere dördüncü haftada verilen ödeve ilişkin veriler analiz edilmiştir. Dönemin ilk kapsamlı ödevi olduğu için bu ödev seçilmiştir.

\subsection{Veri Ön İșleme}

Final sınavına girmeyen 6 öğrencinin verisi analizden çıkartılmış ödeve ilişkin herhangi bir log kaydı olmayan ancak final sınavına giren 8 öğrenci ise araştırmaya dahil edilmiştir. Toplamda 69 öğrenciye ilişkin 2928 satır log verisi analiz edilmiştir. Öğrencilerin bir ödeve ilişkin gerçekleştirebilecekleri tüm aktiviteler Tablo 1'de sunulmuştur. Bir öğrenciye ilişkin log dizisi bu durumlardan hepsini içerebileceği gibi sadece bir ya da birkaç tanesini içerebilir. Aynı zamanda her bir durum, bir log dizisinde birden fazla defa yer alabilir. İncelenen kayıtlar arasında en kısa log dizisi sadece 1 kayıt içerirken en uzun log dizisi 268 kayıttan oluşmaktadır. Ortalama bir log 48 kayıttan oluşurken, ortanca değeri ise 41 'dir. Bir öğrenciye ait 14 kayıttan oluşan örnek bir log dizisi şu şekilde olabilir: Ödev görüntülendi -> Gönderim başlatıldı -> Soru görüntülendi -> Soru görüntülendi -> Soru görüntülendi -> Soru görüntülendi -> Soru görüntülendi -> Soru görüntülendi -> Ödev gönderildi -> Ödev görüntülendi -> Soru gözden geçirildi -> Soru gözden geçirildi -> Soru gözden geçirildi -> Soru gözden geçirildi. Veri ön işleme sürecinde Moodle log kayıtları ön işleme sürecinden geçirilerek her bir öğrencinin ödeve ilişkin gerçekleştirdiği aktiviteler sıralı bir şekilde analiz dosyasına kaydedilmiştir. Bu süreçte kayıtların standartlaştırılması için aralarında üç saniyeden kısa olan geçişler kaydedilmemiştir. 
Tablo 1. Öğrencinin Ödev Gönderme Sürecinde Gerçekleştirebileceği Aktiviteler

\begin{tabular}{|c|c|}
\hline Aktivite & Açıklama \\
\hline Ödev görüntülendi & $\begin{array}{l}\text { Öğrenci ödev modülünü görüntüledi, ödev açıklamasını gördü ancak soruları } \\
\text { açmadı. }\end{array}$ \\
\hline Gönderim başlatıldı & $\begin{array}{l}\text { Bu durum sadece öğrenci ödevi ilk defa açtığında görülmektedir, sonraki } \\
\text { ziyaretlerde bu durum tekrar görülmez. }\end{array}$ \\
\hline Soru görüntülendi & $\begin{array}{l}\text { Öğrencinin ödevdeki her bir soruyu görüntülemesi bu şekilde etiketlenmektedir. } \\
\text { Sorunun görüntülenmesi aynı zamanda cevap alanındaki metnin de } \\
\text { kaydedilmesi anlamına gelmektedir. }\end{array}$ \\
\hline Ödev gönderildi & $\begin{array}{l}\text { Öğrenci ödevi tamamladığında bu durum gerçekleşir. Öğrenci ödevi bir defa } \\
\text { gönderebilir ve gönderdikten sonra cevaplar üzerinde değişiklik yapamaz. }\end{array}$ \\
\hline Soru gözden geçirildi & $\begin{array}{l}\text { Son teslim tarihinden sonra öğrenci ödevi açarsa bu gözden geçirme olarak } \\
\text { etiketlenir. Bu aşamada öğrenci verdiği cevabı görüntüleyebilir ya da ödevi } \\
\text { notlandırılmış ise notunu görebilir. }\end{array}$ \\
\hline
\end{tabular}

Bütün öğrencilere ilişkin log aktiviteleri görsel olarak Şekil 1'de sunulmuştur. Buradan da görüleceği üzere öğrenciler ödev gönderme sürecinde farklı örüntüler izlemektedir. Bazı öğrenciler ödevi gönderme sürecinde çok daha fazla zaman harcarken bazılarının bu süreci hızlı bir şekilde tamamladığı görülmektedir. Aynı şekilde, bazı öğrenciler ödev gönderiminden sonra verdikleri cevapları kontrol ederken, bazıları gönderimden sonra ödevi tekrar açmamışlardır. Bazı öğrencilerin ise ödevi görüntüleyip soruları cevaplamadığı, ödevi göndermediği görülmektedir.

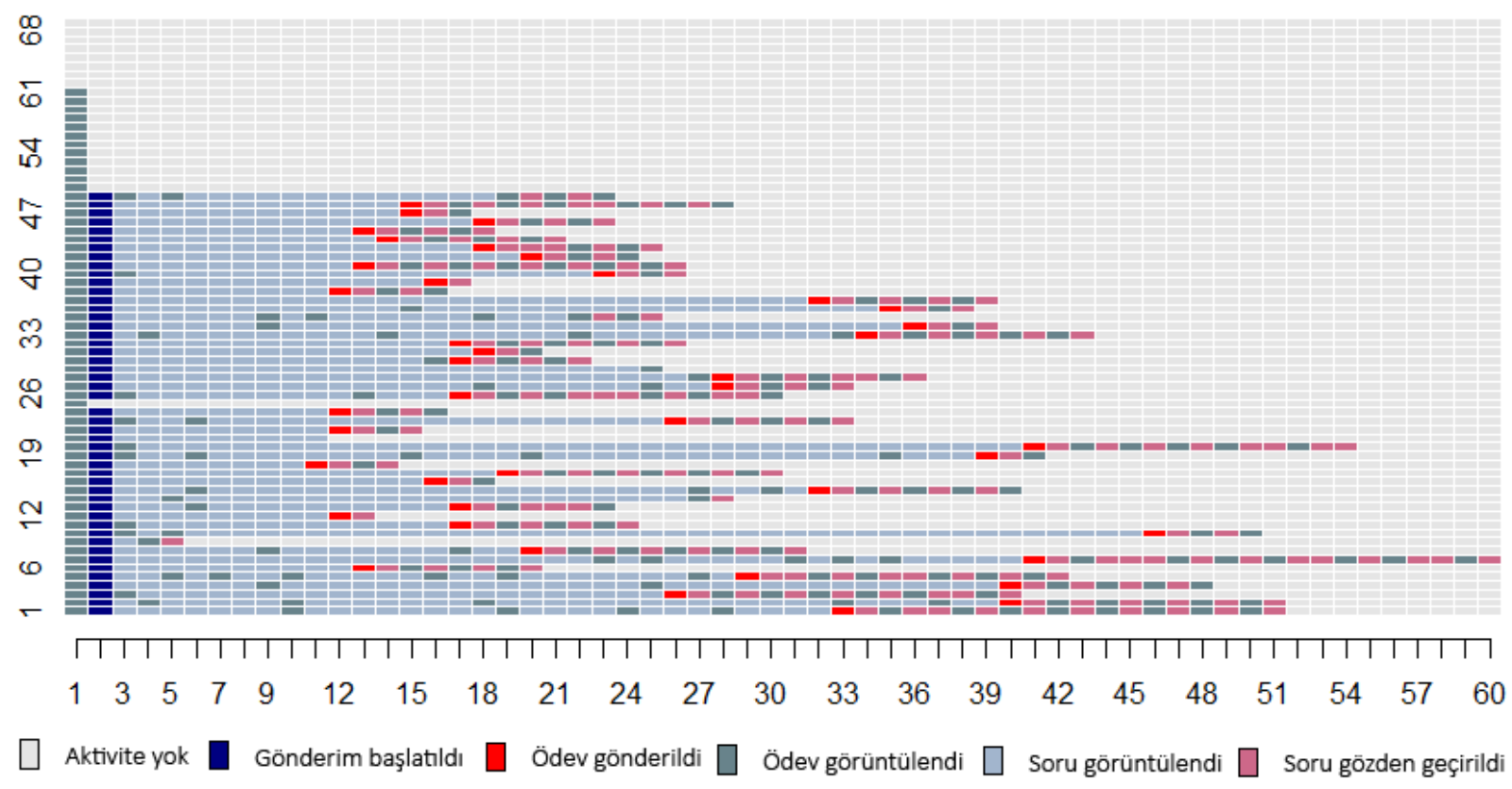

Şekil 1. Öğrencilerin ödev gönderme davranışlarının görsel sunumu

\subsection{Verilerin Analizi}

Veri analizi $\mathrm{R}$ programlama dili ile gerçekleştirilmiştir ( $\mathrm{R}$ Core Team, 2017). Sıralı verilerin görselleştirilmesi ve analiz edilmesi TraMineR (Gabadinho, Ritschard, Müller ve Studer, 2011) paketi ile gerçekleştirilmiştir. Benzer öğrencilerin gruplanması amacıyla Ward uzaklık ölçütünden yararlanılmıştır. Küme sayısına karar vermek için Ward uzaklıkları dendogram şeklinde görselleştirilmiştir. Farklı kümelerde yer alan öğrencilerin ödev gönderme süreçleri süreç madenciliği analizi ile incelenmiştir. Farklı kümelerde yer alan öğrencilerin dönem sonu akademik performansları açısından fark olup olmadığının incelenmesi için ise tek yönlü varyans analizi (ANOVA) gerçekleştirilmiştir.

\section{Bulgular}

\subsection{Kümeleme Analizi}

Şekil 2'de sunulan kümeleme analizi sonuçlarına göre öğrencilerin ödev gönderme verilerine göre iki, üç ya da beş gruba ayrılabileceği görülmektedir. Ward uzaklık ölçüsü dikkate alındığında üç kümenin bu veri seti için uygun olduğuna karar verilmiştir. 


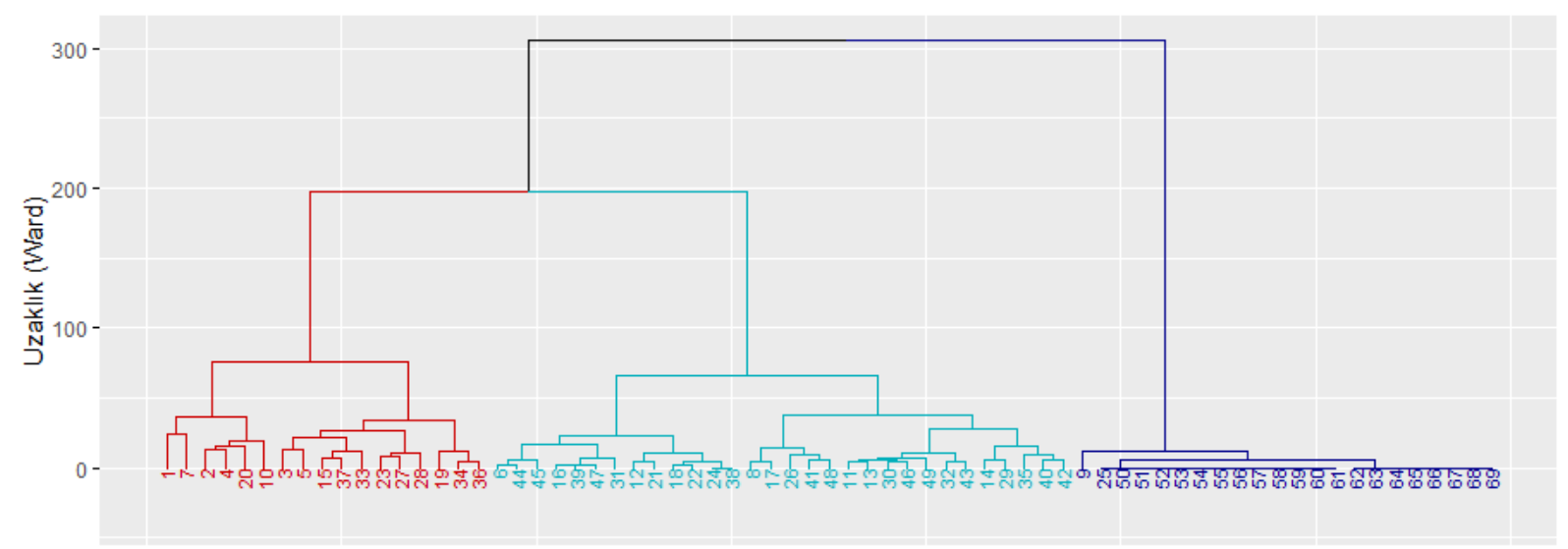

Şekil 2. Kümeleme analizi sonuçları

Her bir kümede yer alan öğrencilerin ödev gönderme davranışları Şekil 3 'te görsel olarak sunulmuştur. Buna göre; ödevini gönderen öğrenciler Küme 1 ve Küme 2'de gruplanırken, Küme 3'deki öğrencilerin ödevi hiç görüntülemeyen ya da bir kere görüntüleyen ama gönderim yapmayan öğrencilerden oluştuğu görülmektedir. Küme 1 ve Küme 2'deki öğrenciler ödev gönderim davranışları incelendiğinde ise, Küme 1'deki öğrencilerin sorular arasında daha fazla gidip geldiği ve ödevi tek bir oturumda tamamlamak yerine birden fazla defa ödevi görüntüleyerek gönderimi zamana yaydıkları görülmektedir. Küme 2'deki öğrenciler ise ödevi daha az adımda tamamlamakla birlikte önemli bir bölümü ödevi tek oturumda tamamlamıştır. Ödevi gönderdikten sonra yapılan gözden geçirme davranışları incelendiğinde ise her iki grupta yer alan öğrencilerin de ödev gönderimi tamamlandıktan sonra ödevi görüntüleyerek ders sorumlusu tarafindan yapılan notlandırmayı kontrol ettikleri ve varsa geribildirimlere baktıkları görülmektedir.

Küme 1

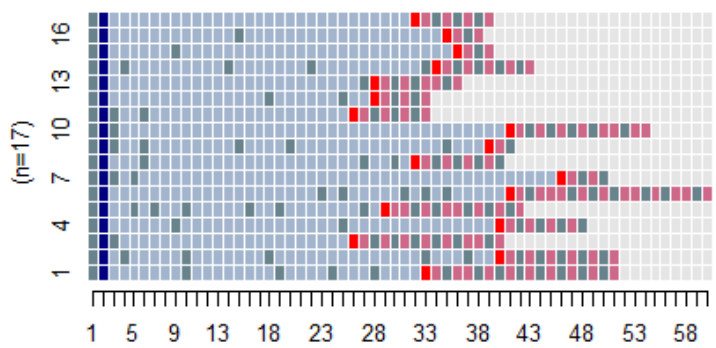

Küme 3

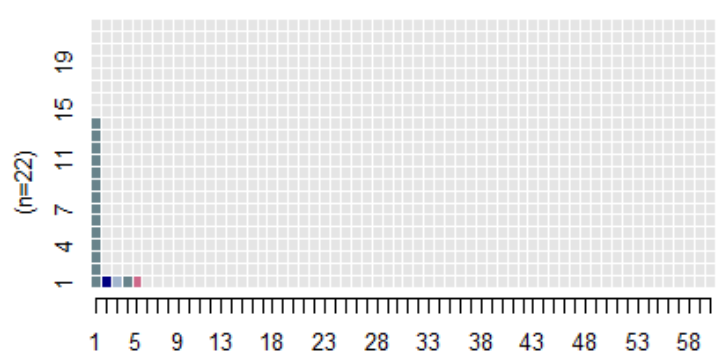

Küme 2

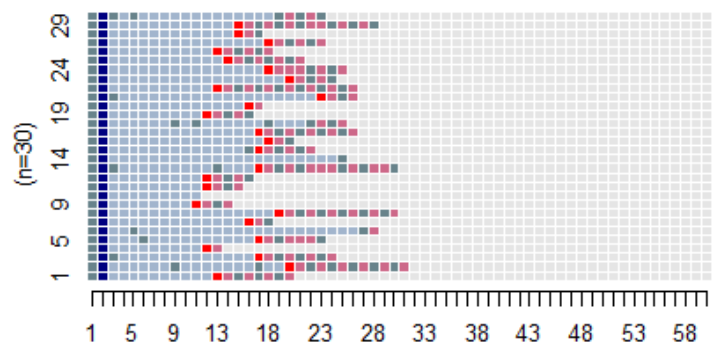

Şekil 3. Her bir kümede yer alan öğrencilerin ödev gönderme davranışları

\section{2. Öğrencilerin Ödev Gönderim Süreçlerinin Modellenmesi}

Ödev, alt sorulardan oluşmaktadır ve her bir soru ayrı bir sayfada yer almaktadır. Öğrencinin ödev modülünü her görüntülemesi Ödev görüntülendi şeklinde kayıt edilmektedir. Öğrencinin ödevi görüntülemesi, ödevin içerisine girmesi anlamına gelmemektedir. Bu nedenle ödevi görüntüleyen bir öğrenci soruları görmek için ilk olarak gönderimi başlatmalıdır. Daha sonra sorular arasında gezinebilmektedir. Bu adım ise Soru görüntülendi olarak kayıt edilmektedir. Öğrenci ödev gönderimi açık olduğu sürece bu aşamada çıkıp istediği zaman tekrar bu aşamadan devam edebilmektedir. Sorular arası gezinim sırasında yazılan cevaplar otomatik olarak kayıt edilmektedir, bu nedenle ayrı bir kaydetme adımı yer almamaktadır. Öğrenci ödevi tamamladıktan sonra son 
aşamada ödev gönderim süresi dolmadan önce ödevini göndermelidir. Bu adım ise Ödev gönderildi şeklinde kayıt edilmektedir. Gönderim tamamlandıktan sonra öğrenci istediği zaman ödevi tekrar açıp sorulara verdiği cevapları gözden geçirebilir, ders sorumlusu tarafından ödevin puanlanması yapıldıktan sonra, öğrenci her bir sorudan aldığı puanı görebilir ve de ders sorumlusunun her bir soru için yazdığı geri bildirimleri okuyabilir. Ödev gönderiminden sonra soruların her görüntülenmesi Soru gözden geçirme olarak kayıt edilmektedir. Sürecin adımlarından olan Gönderim başlatıldı ve Ödev gönderildi adımları her bir öğrenci için bir defa gerçekleşen durumlardır. Ödev görüntülendi, Soru görüntülendi ve Soru gözden geçirildi adımları ise birçok defa gerçekleşebilmektedir.

1. ve 2. kümede yer alan öğrencilerin ödev gönderme süreçleri, süreç madenciliği analizi ile incelenmiş ve sonuçlar Şekil 4'te sunulmuştur. Buna göre; iki kümede ortak olarak, öğrencilerin ödev gönderme sürecinde birisi gönderim süreci ile ilgili bir tanesi gözden geçirme süreci ile ilgili olmak üzere iki örüntü ön plana çıkmaktadır. Ödev gönderim süreci ile ilgili örüntü: Ödev görüntülendi -> Gönderim başlatıldı -> Soru görüntülendi (tekrar) -> Ödev gönderildi şeklindedir. Gözden geçirme süreci ile ilgili örüntü ise: Ödev görüntülendi -> Soru gözden geçirildi şeklindedir. Bu iki örüntüye ek olarak birinci kümede ön plana çıkan bir diğer örüntü ise Ödev görüntülendi -> Soru görüntülendi (tekrar) şeklindedir. Bu durum 1. Kümede yer alan öğrencilerin ödev gönderimini birden fazla oturumda gerçekleştirdiği, 2. Kümede yer alan öğrencilerin ise tek seferde gerçekleştirdiği şeklinde yorumlanabilir.

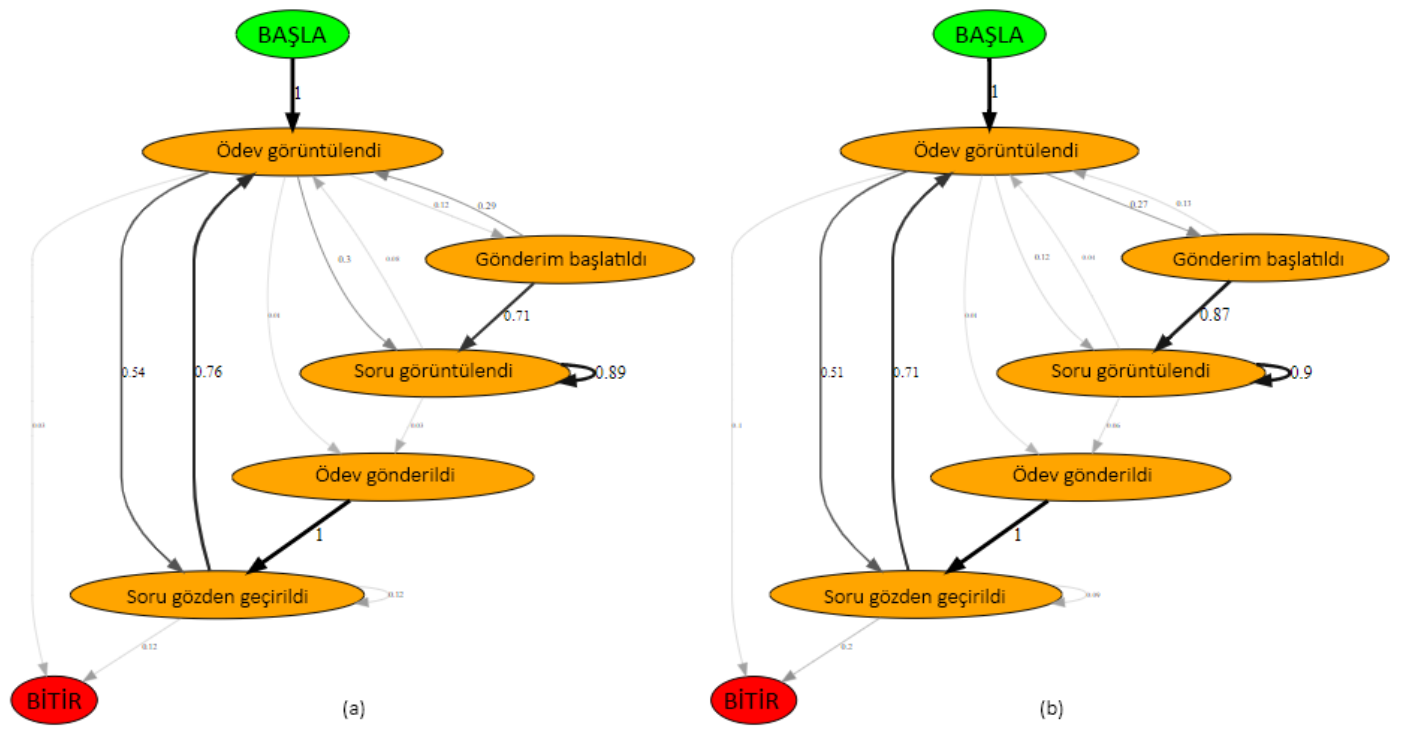

Şekil 4. Küme 1 (a) ve Küme 2'de (b) yer alan öğrencilerin ödev gönderme süreç modelleri

\section{3. Ödev Gönderme Davranışı ve Ders Başarısı Arasındaki İlişkinin İncelenmesi}

Her bir kümede yer alan öğrencilerin dönem sonu akademik performanslarına ilişkin tanımlayıcı istatistikler Tablo 2'de sunulmuştur.

Tablo 2. Tanımlayıcı istatistikler

\begin{tabular}{lccc}
\hline Küme & Öğrenci Sayıs1 & Ortalama & Standart Sapma \\
\hline Küme 1 & 17 & 65,5 & 11,5 \\
Küme 2 & 30 & 60,2 & 15,2 \\
Küme 3 & 22 & 41,8 & 13,0 \\
\hline
\end{tabular}

Öğrencilerin dönem sonu akademik performansları bir ara sınav, bir final sınavı ve dönem içerisinde tamamladıkları ödevlerden aldıkları notlar dikkate alınarak belirlenmiştir. Farklı kümelerde yer alan öğrencilerin dönem sonu akademik performansları açısından fark olup olmadığının incelenmesi için tek yönlü ANOVA analizi gerçekleştirilmiştir. ANOVA sonuçları, Tablo 3'te gösterilmiştir. Kruskall-Wallis analizi ile normallik, Levene analizi ile de varyansların eşitliği test edilmiş ve varsayımların karşılandığı görülmüştür.

Tablo 3. Farklı Ödev Gönderme Davranışı Sergileyen Öğrencilerin Dönem Sonu Akademik Performanslarının Tek Yönlü ANOVA ile Karşılaştırılması

\begin{tabular}{lcccccc}
\hline & Kareler Toplamı & $\begin{array}{c}\text { Serbestlik } \\
\text { Derecesi }\end{array}$ & $\begin{array}{c}\text { Ortalamalar } \\
\text { Karesi }\end{array}$ & F & p & $\begin{array}{c}\text { Etki } \\
\text { Büyüklüğ̈ü }\end{array}$ \\
\hline Gruplar Aras1 & 6479 & 2 & 3240 & 17,27 & $<0,001$ & 0,343 \\
Grup İçi & 12380 & 66 & 188 & & & \\
Toplam & 18859 & 68 & & & & \\
\hline
\end{tabular}


Tablo 3'te sunulan sonuçlar incelendiğinde kümeler arasında ortalama ders başarısı açısından anlamlı fark olduğu görülmektedir $[\mathrm{F}(2,66)=17,27, \mathrm{p}<0,001$, etki değeri $=0,343]$. Farkın hangi gruplar arasında olduğunu belirlemek için Tukey testi kullanılarak post-hoc analizleri yapılmıştır. Tukey testi sonuçlarına göre ortalama ders başarısı açısından Küme 1 ve Küme 2 arasında anlamlı fark olmadığı (p > 0,1), diğer taraftan Küme 1 ve Küme 3 arasında $(p<0,001)$ ve Küme 2 ve Küme 3 arasında $(p<0,001)$ anlamlı fark olduğu görülmüştür. Diğer bir ifade ile Küme 1'deki öğrenciler Küme 3'teki öğrencilerden ortalama 23,7, Küme 2'deki öğrenciler ise Küme 3 'teki öğrencilerden ortalama 18,4 puan daha fazla almışlardır. Küme 1'deki öğrenciler Küme 2'deki öğrencilerden ortalama 5,3 puan daha fazla almışlardır ancak bu fark istatistiksel olarak anlamlı bulunmamıştır.

\section{Tartışma, Sonuç ve Öneriler}

Eğitsel veri madenciliği tekniklerinden kümeleme analizinin ve süreç madenciliğinin işe koşulduğu bu çalışmada, öğrencilerin Moodle öğrenme yönetim sistemindeki ödev gönderim davranışları incelenmiştir. Ödev gönderim davranışları otantik bir öğrenme bağlamı içerisinde öğrencilerin etkileşim verilerine dayalı olarak elde edilmiştir. Öğrenciler ödev gönderim davranışlarına göre profillenmiştir ve ortaya çıkan profillere ilişkin ödev gönderim davranışları süreç madenciliği ile modellenmiştir. Ayrıca farklı ödev gönderim davranışı sergileyen öğrencilerin ders başarıları arasında fark olup olmadığı analiz edilmiştir.

Çalışmanın sonucunda, öğrencilerin ödev gönderim davranışlarına göre üç grupta toplandığını belirlenmiştir. $\mathrm{Bu}$ gruplardan iki tanesi ödevi tamamlayan öğrencilerden oluşurken bir grup ise tamamen ödevi göndermeyen öğrencilerden oluşmuştur. Yapılan süreç madenciliği analizi ödev gönderimi yapan iki grubun daha detaylı olarak karşılaştırılmasına olanak sağlamıştır. Buna göre Küme 1 ve Küme 2'deki öğrencilerin ödev gönderme davranışları arasında benzerlik olmasına karşın bazı noktalarda farklılıklar olduğu görülmüştür. Küme 1 'deki öğrencilerin diğerlerinden farklı olarak ödev gönderimini birden fazla oturumda gerçekleştirdikleri görülmüştür. Bu sonuç, öğrencilerin ödev gönderim davranışlarının birbirlerinden farklılık gösterdiğini ve bazı öğrencilerin ödev sayfaları ile daha fazla etkileşime girdiklerini göstermektedir. Kovanovic ve diğerleri (2015) tarafindan yürütülen çalışmada, öğrencilerin öğrenme görevlerini yerine getirirken sergiledikleri çabalarına dayalı olarak akademik performanslarının yükseldiğini sonucuna ulaşılmıştır. Bu çalışmada ise ödevlerini zamanında gönderen fakat ödev gönderme davranışları arasında farklılık bulunan öğrenci gruplarının ders başarısı arasında anlamlı farklılık bulunamamıştır. Bu nedenle ileriki çalışmalarda öğrencilerin ödev gönderim süreleri de dikkate alınarak yeni modelleme çalışmaları yapılabilir.

Farklı ödev gönderimine sahip öğrencilerin dönem sonu başarıları incelendiğinde ise, ödev gönderimi yapmayan üçüncü kümedeki öğrencilerin \%86'sının dersten başarısız olduğu, diğer taraftan ödev gönderimi yapan Küme 1'deki öğrencilerin \%88'inin, Küme 2'deki öğrencilerin ise \%67'sinin dersten başarılı olduğu görülmüştür. $\mathrm{Bu}$ bulguya benzer şekilde Zacharis (2015) tarafindan yürütülen çalışmada, Moodle öğrenme yönetim sistemi destekli bir karma öğrenme ortamında ödev yükleme sayıları az olan öğrencilerin başarısız olma olasılıklarının yükseldiği sonucuna ulaşmıştır. Ayrıca bu bulgunun, ödevler ile etkileşim verilerinin öğrenci başarısını yordamada anlamlı olduğunu ortaya koyan ilgili çalışma bulgularıyla tutarlılık gösterdiği belirlenmiştir (Kovanovic ve diğerleri, 2015; MacFadyen ve Dawson, 2010). Küme 3'de yer alan ve ödev göndermeyen öğrencilerin ders başarılarının düşük olduğuna dair bulgu ise öğrencilerin ödev gönderimi yapmamasının akademik ertelemeciliğin bir göstergesi olduğuna ve ilgili öğrencilerin daha düşük başarıya sahip olduğuna ilişkin bulguları desteklemektedir (Cerezo ve diğerleri, 2017; You, 2015, 2016). Dolayısıyla bu bulguya dayalı olarak, karma öğrenme sürecinde öğrenci başarısını artırmak için öğrencilerin çevrimiçi ödevlerle etkileşimini artırmaya dönük otomatik müdahalelerin ve anlık geribildirimlerin verilmesi önerilebilir. Bununla birlikte öğrenme analitiklerine dayalı gösterge panellerinde öğrencilerin ödev gönderme davranışlarına dönük verilerin dikkate alınması gerektiği ifade edilebilir.

Elde edilen bulgular dönem sonunda başarısız olacak öğrencilerin dersin ilk haftalarında belirlenmeleri amacıyla kullanılabilir. Bu aşamada yapılacak müdahaleler, öğrencilerin olası başarısızlıklarını önlemede etkili olabilir. Yapılan çalışmalar dersin ilk haftalarından itibaren öğrencilerin dönem sonu performanslarının önemli ölçüde tahmin edilebileceğini göstermektedir (Akçapınar, Altun ve Aşkar, 2019). İleriki çalışmalarda özellikle dersten başarısız olma ihtimali yüksek öğrencilere yönelik müdahalelerin tasarlanması ve test edilmesi önemlidir. Bu çalışmada dönemin ilk kapsamlı ödevi olduğu için öğrencilere dördüncü haftada verilen ödeve ilişskin veriler analiz edilmiştir. Bu durum, çalışmanın sınırlıklarından biridir. İleriki çalışmalarda ödevin zorluk derecesine ve bireysel farklılıklara göre davranış örüntülerinin değişip değişmediği incelenebilir.

Etik Kurul Onay Bilgileri: Araştırma ile ilgili Trabzon Üniversitesi Sosyal ve Beşeri Bilimler Bilimsel Araştırma ve Yayın Etik Kurulu'ndan 05/03/2020 tarih ve 81614018-000.E109 sayı numarası ile etik kurul uygunluk onayı alınmıştır. 


\section{References}

Akçapınar, G., Altun, A., \& Aşkar, P. (2019). Using learning analytics to develop early-warning system for atrisk students. International Journal of Educational Technology in Higher Education, 16(1), 40.

Bayrak, F. (2018). Üniversite öğrencilerinin karma öğrenme ortamındaki akademik erteleme davranışları. Ege Ĕgitim Dergisi, 19(2), 470-487.

Broadbent, J. (2017). Comparing online and blended learner's self-regulated learning strategies and academic performance. The Internet and Higher Education, 33, 24-32.

Cerezo, R., Sánchez-Santillán, M., Paule-Ruiz, M. P., \& Núñez, J. C. (2016). Students' LMS interaction patterns and their relationship with achievement: A case study in higher education. Computers \& Education, 96, 4254.

Cerezo, R., Esteban, M., Sánchez-Santillán, M., \& Núñez, J. C. (2017). Procrastinating behavior in computerbased learning environments to predict performance: A case study in Moodle. Frontiers in Psychology, 8, 1403. doi: 10.3389/fpsyg.2017.01403

Conijn, R., Snijders, C., Kleingeld, A., \& Matzat, U. (2017). Predicting Student Performance from LMS Data: A Comparison of 17 Blended Courses Using Moodle LMS. IEEE Transactions on Learning Technologies, 10(1), 17-29. doi:10.1109/tlt.2016.2616312

Dabbagh, N., \& Kitsantas, A. (2005). Using web-based pedagogical tools as scaffolds for self-regulated learning. Instructional Science, 33(5-6), 513-540.

Gabadinho, A., Ritschard, G., Müller, N. S., \& Studer, M. (2011). Analyzing and visualizing state sequences in $\mathrm{R}$ with TraMineR. Journal of Statistical Software, 40(4), 1-37.

Graham, C. R. (2006). Blended learning systems: Definition, current trends, and future directions. In C. J. Bonk, \& C. R. Graham (Eds.), The handbook of blended learning: Global perspectives, local designs (pp. 3e21). San Francisco: Pfeiffer. http://doi.org/10.2307/4022859.

Huang, S., \& Fang, N. (2013). Predicting student academic performance in an engineering dynamics course: A Comparison of four types of predictive mathematical models. Computers \& Education, 61, 133-145.

Jo, II-Hyun, Park, Y., Kim, J., \& Song, J. (2014). Analysis of online behavior and prediction of learning performance in blended learning environments. Educational Technology International, 15(2), 71-88.

Kokoç, M., \& Altun, A. (2019). Building a learning experience: What do learners' online interaction data imply? In D. G. Sampson, D. Ifenthaler, J. M. Spector, P. Isaias, \& S. Sergis (Eds.), Learning technologies for transforming teaching, learning and assessment at large scale (pp.55-70). New York, NY: Springer.

Kovanović, V., Gašević, D., Dawson, S., Joksimović, S., Baker, R. S., \& Hatala, M. (2015, March). Penetrating the black box of time-on-task estimation. In Proceedings of the Fifth International Conference on Learning Analytics and Knowledge (pp. 184-193). New York, NY: ACM.

Lim, J. M. (2016). The relationship between successful completion and sequential movement in self-paced distance courses. International Review of Research in Open and Distributed Learning, 17(1), 159-179.

Lu, O. H. T., Huang, A. Y. Q., Lin, A. J. Q., Ogata, H., \& Yang, S. J. H. (2018). Applying learning analytics for the early prediction of students' academic performance in blended learning. Educational Technology \& Society, 21(2), 220-232.

Macfadyen, L. P., \& Dawson, S. (2010). Mining LMS data to develop an "early warning system" for educators: A proof of concept. Computers \& education, 54(2), 588-599.

Michinov, N., Brunot, S., Le Bohec, O., Juhel, J., \& Delaval, M. (2011). Procrastination, participation, and performance in online learning environments. Computers \& Education, 56, 243-252.

Paule-Ruiz, M. P., Riestra-Gonzalez, M., Sánchez-Santillan, M., \& Pérez-Pérez, J. R. (2015). The Procrastination related indicators in e-learning platforms. Journal of Universal Computer Science, 21(1), 722.

Porter, W. W., Graham, C. R., Spring, K. A., \& Welch, K. R. (2014). Blended learning in higher education: Institutional adoption and implementation. Computers \& Education, 75, 185-195.

Prasad, P. W. C., Maag, A., Redestowicz, M., \& Hoe, L. S. (2018b). Unfamiliar technology: Reaction of international students to blended learning. Computers \& Education, 122, 92-103.

R Core Team. (2017). R: A language and environment for statistical computing: $R$ Foundation for Statistical Computing. Retrieved October 28, 2019 from https://www.R-project.org/

Rasheed, R. A., Kamsin, A., \& Abdullah, N. A. (2020). Challenges in the online component of blended learning: A systematic review. Computers \& Education, 144, 103701.

Smyth, S., Houghton, C., Cooney, A., \& Casey, D. (2012). Students' experiences of blended learning across a range of postgraduate programmes. Nurse Education Today, 32(4), 464-468.

You, J. W. (2015). Examining the effect of academic procrastination on achievement using LMS data in eLearning. Educational Technology \& Society, 18(3), 64-74.

You, J.W. (2016). Identifying significant indicators using LMS data to predict course achievement in online learning. Internet and Higher Education, 29, 23-30.

Zacharis, N. Z. (2015). A multivariate approach to predicting student outcomes in web-enabled blended learning courses. The Internet and Higher Education, 27, 44-53. 